\title{
PENGEMBANGAN APLIKASI SISTEM PENILAIAN PRAKTIK PENGALAMAN LAPANGAN PADA FAKULTAS ILMU KOMPUTER UNIVERSITAS BRAWIJAYA BERBASIS WEB
}

\author{
Rizky Tri Sulistyo ${ }^{1}$, Faizatul Amalia*2, Tri Afirianto ${ }^{2}$ \\ ${ }^{1,2,3}$ Fakultas Ilmu Komputer, Universitas Brawijaya Malang \\ Email: 1'rizkytri_s@student.ub.ac.id; ${ }^{2}$ faiz_amalia@ub.ac.id; ${ }^{3}$ tri.afirianto@ub.ac.id \\ *Penulis Korespondensi
}

(Naskah masuk: 05 Januari 2021, diterima untuk diterbitkan: 18 Oktober 2021)

\begin{abstract}
Abstrak
Praktik Pengalaman Lapangan (PPL) merupakan mata kuliah bidang pedagogi yang wajib ditempuh oleh semua mahasiswa Strata 1 (S1) Program Studi (PRODI) Pendidikan Teknologi Informasi (PTI) Jurusan Sistem Informasi (SI) Fakultas Ilmu Komputer (FILKOM) Universitas Brawijaya (UB) untuk menerapkan tenaga pendidik profesional di bidang Teknologi Informasi dan Komunikasi (TIK). Tujuan dari penilaian PPL merupakan untuk memperoleh informasi akurat tentang tingkat pencapaian kemampuan atau kompetensi mahasiswa dalam melaksanakan hak dan kewajiban dalam PPL. Namun, selama proses pelaksanaan PPL semua aktivitas masih dilakukan luring. Hal ini memiliki dampak adanya batasan ruang dan waktu untuk para penilai, pengarsipan dokumen penilaian kurang termonitor, dan manipulasi penilaian oleh mahasiswa. Sehingga perlu mengoptimalkan pengelolaan dalam sistem penilaian PPL dengan solusi aplikasi sistem penilaian PPL berbasis web yang dapat diakses dari peramban apapun. Pengembangan aplikasi sistem penilaian PPL diciptakan berbasis website. Model Waterfall merupakan metode pengembangan aplikasi yang telah digunakan. Pengujian aplikasi sistem penilaian PPL dilaksanakan melalui pengujian white-box (pengujian unit dan integrasi), pengujian blackbox (pengujian validasi), dan pengujian compatibility dengan sortsite. Berdasarkan dari pengujian pada sestiap kasus uji di aplikasi sistem penilaian menandakan bahwa 100\% valid dan dapat dijalankan diberbagai peramban, yaitu (1) IE; (2) Edge; (3) Firefox; (4) Safari; (5) Opera; (6) Chrome; (7) iOS; (8) Android.
\end{abstract}

Kata kunci: pengembangan sistem informasi, penilaian PPL, web, model waterfall

\section{THE DEVELOPMENT OF WEB-BASED APPLICATION FIELD EXPERIENCE PRACTICE ASSESSMENT SYSTEM FOR FACULTY OF COMPUTER SCIENCE BRAWIJAYA UNIVERSITY}

\begin{abstract}
Field Experience Practice (FEP) is a pedagogy course that must be taken by all students of study program Information Technology Education (ITE) Department of Information Systems Faculty of Computer Science at Brawijaya University to apply professional educators in the field of Information and Communication Technology (ICT). The purpose of FEP assessment is to obtain accurate information about the level of achievement of students' ability or competence in carrying out rights and obligations in FEP. However, during the FEP implementation process all activities are still carried out offline. This has the effect of limiting space and time for assessors, archiving of undermonitored assessment documents, and manipulation of assessments by students. So it is necessary to optimize the management in the FEP assessment system with a web-based FEP assessment system application solution that can be accessed from any browser. The development of FEP assessment system application was created based on the website. Waterfall model is an application development method that has been used. FEP assessment system application testing is conducted through white-box testing (unit testing and integration), black-box testing (validation testing), and compatibility testing with sortites. Based on testing on a single test case in the application the assessment system indicates that it is $100 \%$ valid and can be run in various browsers, namely (1) IE; (2) Edge; (3) Firefox; (4) Safari; (5) Opera; (6) Chrome; (7) iOS; (8) Android.
\end{abstract}

Keywords: information system development, FEP assessment, web, waterfall model 


\section{PENDAHULUAN}

Penilaian PPL memiliki dua komponen penilaian utama, yaitu penilaian PPL 1 untuk menilai mutu dengan cara menguji keterampilan teknis dan non-teknis mahasiswa dalam persiapan pelaksanaan secara nyata dalam pembelajaran, pelaksanaan terkait pelaksanaan secara nyata pembelajaran sejawat, diiringi perilaku mahasiswa sebagai guru model selama PPL 1 dan penilaian PPL 2 untuk menilai mutu dengan cara menguji keterampilan teknis dan non-teknis mahasiswa dalam persiapan pelaksanaan secara nyata pembelajaran, pelaksanaan praktik pembelajaran, serta perilaku mahasiswa sebagai guru model selama PPL 2 (PPL, 2018).

Berdasarkan hasil observasi di FILKOM UB pada pelaksanaan PPL PRODI PTI pada tahun ajaran 2019/2020 semester ganjil dan genap. Alur mendapatkan Form penilaian dilakukan secara mandiri oleh mahasiswa dengan meminta ke akademik PRODI PTI atau mencetak dokumen buku panduan dari ekstensi $p d f$ dikonversi menjadi docx. Mahasiswa, dosen, dan guru pamong mengisi tiap dokumen penilaian sesuai dengan penilaian yang cocok diberikan kembali kepada mahasiswa, dosen, dan terakhir di akademik PRODI PTI. Akademik PRODI PTI memasukkan hasil dari penilaian dan menyimpan kertas cetak dokumen. Selama proses awal sampai akhir dilakukan dengan manual yaitu masih menggunakan dokumen penilaian secara cetak. Sehingga pada saat mahasiswa memerlukan form penilaian ke akademik dialihkan ke himpunan Keluarga Besar Mahasiswa Pendidikan Teknologi Informasi (KBMPTI) dengan tujuan membantu konversi dokumen ekstensi pdf menjadi docx. Mahasiswa mencetak dokumen dari modifikasi dan disimpan sementara sampai dokumen diserahkan kepada dosen, guru pamong dan Program Studi PTI. Namun, jika dokumen fisik hilang maka mengulang kembali alur dari awal. Sehingga mahasiswa perlu waktu lebih lama karena alur yang lebih panjang.

Berdasarkan hasil wawancara dengan pihak instansi FILKOM UB dan salah satu pihak instansi SMK Negeri 4 Malang, Bapak Dhika Wirya Dipraja, S.T. selaku akademik PRODI PTI, Bapak Satrio Hadi Wijoyo, S.Si., S.Pd., M.Kom. selaku koordinator pelaksanaan PPL sekaligus dosen pembimbing PPL dan Ibu Septi Retno Desi Purnoningtyas, S.Pd selaku guru pamong PPL bahwa kegiatan pendataan penilaian praktik pengalaman lapangan masih secara manual. Proses pendataan menggunakan microsoft excel menulis satu-satu di buku yaitu hanya nilai akhir. Nilai akhir langsung dimasukkan ke dalam SIAM (Sistem Informasi Akademik Mahasiswa) dan dokumen fisik form tidak disimpan secara daring. Sehingga tidak ada pengarsipan dan apabila dibutuhkan sewaktu-waktu harus mencari secara luring. Penyimpanan secara daring melakukan hasil scan dari mahasiswa mempermudah apabila data ini dibutuhkan sewaktu-waktu. Dosen pembimbing dan guru pamong yang hanya bisa memberikan nilai di Form penilaian namun secara proses mahasiswa yang mengelola dan membawa dokumen fisik form penilaian sehingga ada kemungkinan mahasiswa dapat memanipulasi penilaian. Dosen pembimbing, guru pamong dan akademik tidak dapat mengakses tanpa batasan ruang dan waktu karena harus bersua satu sama lain dengan mahasiswa untuk memberikan form penilaian.

Penilaian secara manual yang ada di sistem penilaian PPL di FILKOM UB seringkali terjadi beberapa permasalahan, yaitu (1) dokumen penilaian ketika melakukan konversi dari ekstensi $p d f$ ke ekstensi docx mengalami kegagalan konversi; (2) mahasiswa atau dosen tidak bisa konversi tanpa aplikasi konversi dokumen; (3) apabila ingin melakukan perubahan nilai dari penilaian PPL lambat untuk dimutakhirkan karena dokumen penilaian kurang tersimpan dengan baik; (4) penyimpanan arsip dokumen penilaian PPL kurang termonitor sehingga menyebabkan arsip tercecer dan hilang; (5) rentan manipulasi nilai oleh mahasiswa; (6) pemberi nilai tidak bisa memberikan penilaian karena ada batasan waktu dan tempat bersua satu sama lain antara pemberi nilai dengan mahasiswa. Sehingga FILKOM UB perlu mengoptimalkan pengelolaan dalam sistem penilaian PPL dengan solusi aplikasi sistem penilaian PPL berbasis web yang dapat diakses dari peramban apapun.

Dalam penelitian pengembangan aplikasi sistem penilaian praktik penilaian lapangan ini terdapat beberapa penelitian sebelumnya yang juga mengembangkan sistem informasi dilakukan oleh Sumbaryadi \& Christo (2019) bahwa dalam penelitiannya diciptakan pegembangan karya perangkat lunak untuk sekolah mengenai pengolahan data nilai sesuai objek penelitiannya, yaitu Sekolah Menengah Kejuruan (SMK). Dalam penelitian peneliti mengungkapkan bahwa pengolahan data tersistem paripurna bisa memaparkan hasil nilai rapot untuk dijadikan hasil evaluasi yang mumpuni sehingga perlu sistem pengolahan data dengan sistem terkomputerisasi.

Selanjutnya penelitian kedua terdapat penelitian yang mengembangkan sistem informasi yang dilakukan oleh Rahmawati, dkk., (2016) bahwa aplikasi tercipta cakap menawarkan sarana kepada pengajar sesuai pelajaran diampu untuk mengisi nilai. Aplikasi dapat mengatasi data non-integrasi, tingkat redundan atau kesamaan data yang tinggi, aktivitas memakan waktu yang tidak sedikit disebabkan oleh data ditaruh secara digital dengan dokumen dan lembar tidak identik karena telah menggunakan perangkat lunak Microsoft Excel.

Selanjutnya penelitian ketiga terdapat penelitian yang mengembangkan sistem informasi yang dilakukan oleh Maryono \& Suryadini (2017). Melalui penelitian ini dipaparkan bahwa kecakapan sistem informasi pengolahan nilai siswa yang dijalankan aktivitasnya dalam penelitian ini mempermudah dan layak digunakan dalam mengelola nilai rapor siswa dengan nilai 93,1 hitungan persen dari ahli sistem, 85,3 hitungan persen dari guru dan staf tata usaha dan 82,4 hitungan persen dari siswa.

Selanjutnya penelitian keempat terdapat penelitian yang mengembangkan sistem informasi yang dilakukan 
oleh Mahmudi (2015) bahwa untuk meningkatkan kualitas proses pembelajaran serta peningkatan kualitas internal dilakukan pengembangan berbasis web. Sistem telah dibuat dapat mempermudah mahasiswa, dosen dan karyawan dalam pengisian kuesioner. Sistem dapat melakukan monitoring dan evaluation lebih efektif dan efisien daripada penyebaran kuesioner secara manual. Sehingga laporan hasil evaluation mumpuni sebagai acuan pengguna sistem seperti pihak manajemen iterasi tiap semester dalam pemberian sistem hadiah (reward) bagi dosen dan karyawan.

Selanjutnya penelitian kelima terdapat penelitian yang mengembangkan sistem informasi yang dilakukan oleh Faisal \& Harison (2017) dari kalkulasi 2500 data angket mahasiswa berbasis web. Memberikan nilai secara detail dan tepat dari aktivitas evaluasi penilaian rendah dan tinggi yang bisa jadi bukan kelebihan dosen melalui hasil mengumpulkan semua nilai dari aplikasi tercipta untuk mahasiswa dan mahasiswi yang secara sadar telah memberikan penilaian kuesioner. Hasil penilaian dapat dikumpulkan sekarang juga tanpa ada batasan ruang dan waktu melihat nilai dosen yang tinggi ataupun rendah dari sistem informasi universitas yang tercipta.

Berdasarkan kelima penelitian tersebut ditarik kesimpulan bahwa pada kecapakan kecanggihan sebuah teknologi yakni sistem informasi berbasis web mempermudah ataupun layak digunakan dalam pengolahan data nilai. Penilaian dapat diakses oleh penilai dari manapun dan menjadi evaluasi nilai. Persamalahan yang dialami dari objek penelitian juga sudah terpaparkan di awal sehingga koheren apabila menggunakan metode waterfall dalam pengembangan sistem informasi karena kebutuhan juga didapatkan melalui observasi dan wawancara juga.

\section{METODE PENELITIAN}

Metode yang diimplementasikan dalam pengembangan aplikasi sistem penilaian PPL merupakan metode waterfall sesuai pada Gambar 1.

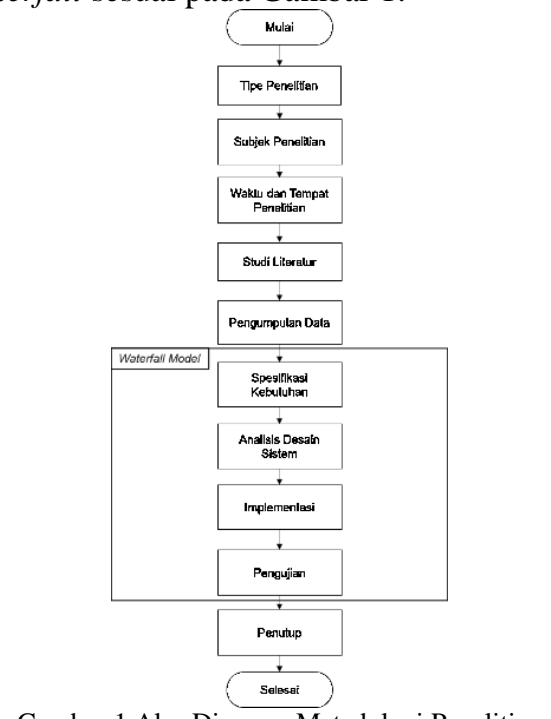

Gambar 1 Alur Diagram Metedologi Penelitian

\subsection{Tipe Penelitian}

Tipe penelitian yang digunakan dalam penelitian ini merupakan tipe implementatif menghasilkan produk atau artefak utama seperti perangkat lunak atau model konseptual atau rancangan dari perangkat lunak. Penelitian dengan tipe implementatif terlaksana melalui metode waterfall model. Bagian yang utama dari metode pengembangan perangkat lunak waterfall model merupakan pengembangan terlaksana secara berturutturut atau berbentuk tahap satu-satu linear untuk tiap tahap sehingga satu tahap tidak bisa paripurna apabila ada tahap yang belum selesai untuk lanjut (Sommervile, 2016).

\subsection{Subjek Penelitian}

Subjek penelitian diteliti merupakan sistem penilaian praktik pengalaman lapangan pada Fakultas Ilmu Komputer Universitas Brawijaya.

\subsection{Tempat dan Waktu Penelitian}

Penelitian dilaksanakan di Fakultas Ilmu komputer Universitas Brawijaya untuk memperoleh data dari akademik prodi PTI dan dosen pembimbing PTI untuk pelaksanaan praktik pengalaman lapangan prodi PTI. Penelitian dilaksanakan di SMK Negeri 4 Malang untuk memperoleh data dari guru pamong untuk pelaksanaan praktik pengalaman lapangan prodi PTI. Penelitian dilaksanakan pada pelaksanaan PPL 2019/2020 Ganjil dan Genap.

\subsection{Studi literatur}

Studi literatur dilaksanakan dengan langkah penciptaan atau ada yang berhubungan terhadap himpunan pengerjaan demi mencapai kepahaman dari para ahli yang telah memberikan pendapat dan dapat dikutip. Langkah-langkah peneliti gunakan agar mengulik cakrawala berpikir dari berbagai sumber seperti jurnal dan buku maupun jejaring daring pada situs yang diakses oleh peramban yang ada korelasi dengan masalah di penelitian.

\subsection{Pengumpulan Data}

Pengumpulan data dilaksankanan dalam tujuan mendapatkan wawasan diperlukan dalam aktivitas penelitian, hal diperlukan seperti sumber informasi berupa data digunakan dalam proses analisis dan seluk beluk mengenai kebutuhan dalam menginterpretasikan sistem. Metode pengumpulan data yang dilakukan yakni observasi dan wawancara.

\subsection{Spesifikasi Kebutuhan}

Spefikasi kebutuhan dilaksanakan dengan aktivitas proses identifikasi pengguna sistem yang menggunakan perangkat lunak diciptakan oleh pengembang perangkat lunak. Tahap spesifikasi kebutuhan mengetahui dan memvisualisasikan kebutuhan-kebutuhan diperlukan oleh pengguna sistem maupun sistem itu sendiri. 
Spesifikasi kebutuhan menggunakan metode yang cocok yaitu use case diagram dan use case scenario untuk memvisualisasikan kebutuhan-kebutuhan yang diperlukan.

\subsection{Analisis Desain Sistem}

Analisis desain sistem dilaksanakan dengan aktivitas analisis perancangan desain untuk mempermudah peneliti dalam proses pengembangan perangkat lunak. Tahap analisis desain sistem memiliki tujuan hasil seperti dokumen perancangan sebagai pedoman atau panduan awal cipta sistem. Pengembang perangkat lunak membuat analisis desain dengan pendekatan perancangan berbasis objek dari dokumendokumen yaitu (1) Sequence Diagram; (2) Class Diagram; (3) Perancangan Basis Data Firestore; (4) Perancangan Algoritme (5) User Interface Design.

\subsection{Implementasi}

Implementasi dilaksanakan dengan aktivitas pengodean untuk perangkat lunak yang diimplementasikan sesuai dengan perancangan telah dimodifikasi sedemikian rupa dengan memakai bahasa pemrograman seperti Javascript dibantu dengan HTML, CSS dan memakai cloud firestore API Firebase.

\subsection{Pengujian}

Pengujian dilaksanakan dengan aktivitas untuk mengetahui hasil pengodean dari pengembang perangkat lunak apakah sistem sesuai dengan kebutuhan pengguna sistem dan mengetahui tingkat kelayakan sistem perangkat lunak. Pengujian yang dilaksanakan yaitu pengujian white-box (pengujian unit dan integrasi), pengujian black-box (pengujian validasi), dan pengujian compatibility.

\subsection{Penutup}

Penutup dilaksanakan pada tahap penarikan kesimpulan aktivitas paling akhir dari serangkaian proses telah dilakukan oleh peneliti dalam melakukan pengembangan. Saran mempunyai makna untuk mengadisi pola pikir yang berupa selain nilai lebih yang telah diseleksi dalam penelitian dan cakrawala ilmu untuk peneliti yang akan datang mengenai metode atau langkah-langkah yang digunakan.

\section{HASIL DAN PEMBAHASAN}

Penciptaan pengembangan aplikasi sistem penilaian dilaksanakan mulai dari menjelaskan bagaimana perancangan dan implementasi hingga pengujian perangkat lunak dalam pengembangan aplikasi sistem penilaian praktik pengalaman lapangan. Tahapan-tahapan dilaksanakan sebagai berikut.

\subsection{Hasil Analisis Kebutuhan}

Dilaksanakan analisis kebutuhan untuk memperoleh uraian terstruktur dan rinci dalam proses identifikasi pengguna, analisis spesifikasi kebutuhan fungsional dan spesifikasi kebutuhan non-fungsional, use case diagram, dan use case scenario dari tiap pengguna sistem yang turut andil dalam aplikasi sistem penilaian PPL dari analisis permasalahan hasil observasi, hasil wawancara dan dokumen penyokong penilaian PPL. Pada Gambar 2 menunjukkan use case diagram sistem informasi penilaian PPL yang telah tercipta.

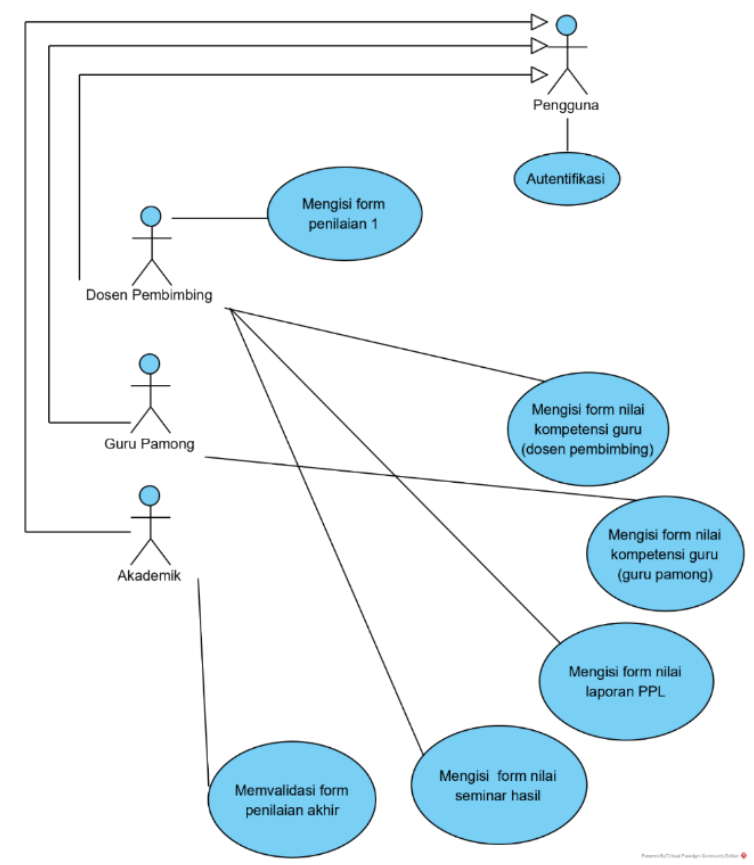

Gambar 2 Use Case Diagram Sistem Informasi Penilaian PPL

\subsection{Hasil Perancangan}

Dilaksanakan perancangan untuk memperoleh rancangan berupa sequence diagram, class diagram, perancangan basis data firestore, perancangan algoritme, dan user interface design.

\subsubsection{Sequence Diagram}

Sequence diagram menjelaskan mengenai alur suatu pogram yang kelak diimplementasikan terhadap pengembangan sistem atau untuk memahami dari alur data dan program yang sedang berlangsung di area sistem. Pada Gambar 3 menunjukkan sequence diagram dosen pembimbing engisi form penilaian 1 yang telah tercipta. Proses dosen pembimbing melakukan mengisi form penilaian 1 terdiri dari Aktor Dosen Pembimbing, Boundary DashboardDosenPembimbing, Boundary FormPenilaian $1, \quad$ Controller Controller_DosenPembimbing, dan Entity Cloud_Firestore. Sequence diagram Gambar 4.5 memiliki alur, yaitu (1) dosen pembimbing mengakses sistem; (2) sistem mengakses Form Penilaian 1 dan menampilkan halaman FormPenilaian 1; (3) controller mengisi form penilaian 1 untuk disimpan dan diberikan kepada basis data cloud firestore; (4) sistem akan menyimpan berdasarkan id mahasiswa yang dinilai yang dipilih oleh dosen pembimbing; (5) jika mengisi form 
penilaian 1 tidak lengkap maka tidak bisa lanjut ke proses selanjutnya.

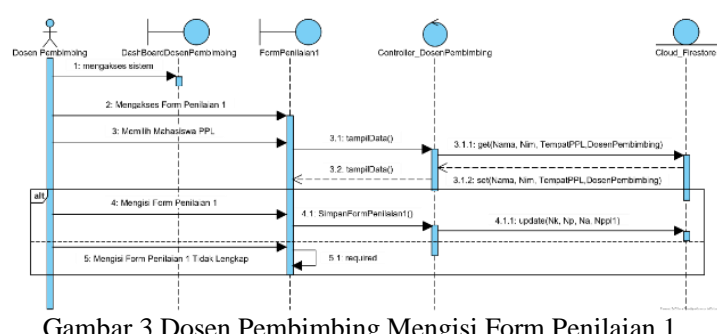

\subsubsection{Class Diagram}

Class diagram menjelaskan mengenai point of view/ viewpoint (sudut pandang) berdasrkan kelas-kelas (classes) dan koheren antar sistem dari sistem yang telah tercipta. Kelas (class) tercipta yaitu, (1)Controller_Dosen Pembimbing ; (2)Controller_GuruPamong; (3) Controller_Akademik. Pada Gambar 4 menunjukkan perancangan class diagram controller yang telah tercipta.

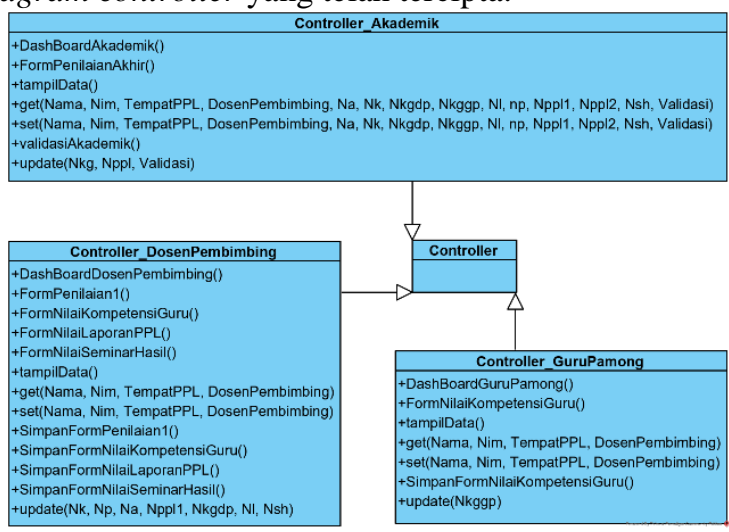

Gambar 4 Perancangan Class Diagram Controller

\subsubsection{Perancangan Basis Data Firestore}

Perancangan Basis Data Firestore merupakan tahap visualisasi dari pengembang untuk menunjukkan struktur basis data yang diimplementasikan. Penciptaan sistem informasi menggunakan platform firebase dengan basis data cloud firestore terdiri dari uraian list terdiri dari collection, document, dan data. Pada Gambar 5 dan 6 menunjukkan menunjukkan struktur basis data dan JSON users-dospem yang telah tercipta.

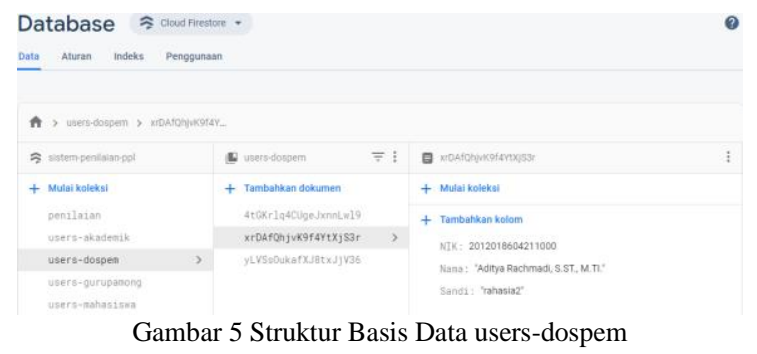

Pada basis data firestore users-dospem terdiri dari root dimulai dengan collection users-dospem dan berisi child berupa document xrDAfQhjvK9f4YtXjS3r dan seterusnya yang berfungsi sebagai id unik. Setiap id memiliki collection yang memiliki data, yaitu (1) NIK dengan tipe data number; (2) Nama dengan tipe data String; (3) Sandi dengan tipe data String.

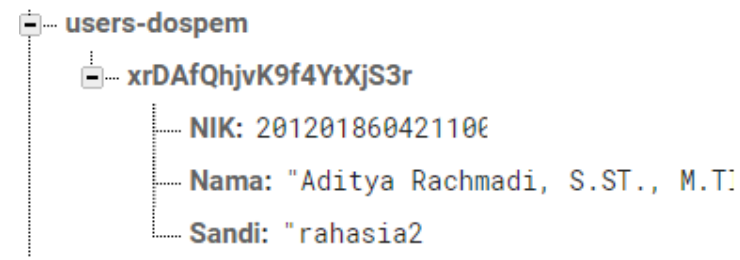

Gambar 6 Struktur JSON users-dospem

\subsubsection{Perancangan Algoritme}

Perancangan algoritme merupakan tahap penguraian yang telah dilakukan ketika proses berjalan himpunan alur operasi logika sebagai panduan atau panutan pengembangan menerapkan konsep fungsifungsi yang ada di sistem informasi. Pada rancangan algoritme mengisi form penilaian 1. Algoritme dimulai dengan aktor memilih penilaian 1 dan memilih uraian mahasiswa PPL yang tampil kemudian apabila telah dipilih akan menampilkan form penilaian 1. Aktor mengisi form penilaian 1 dengan semua variabel tersedia, jika pengisian telah terisi semua, maka menampilkan pesan "Nilai telah tersimpan". Jika, pengisian belum lengkap maka menampilkan "Periksa kembali, ada nilai belum terpenuhi”.

\subsubsection{User Interface Design}

User interface design (desain antarmuka pengguna) merupakan visualisasi dengan hasil dari sketsa tampilan untuk mempermudah pengembang ketika masuk proses tahap implementasi. Pada Gambar menunjukkan menunjukkan user interface design dosen pembimbing mengisi form penilaian 1 yang telah tercipta. Pada user interface design sistem informasi penilaian PPL terdiri dari beberapa perancangan antarmuka, yaitu (1) dosen pembimbing mengisi form penilaian 1; (2) dosen pembimbing mengisi form nilai kompetensi guru; (3) dosen pembimbing mengisi form nilai laporan PPL; (4) dosen pembimbing mengisi form nilai seminar hasil; (5) guru pamong mengisi form nilai kompetensi guru; (6) akademik memvalidasi form penilaian akhir.

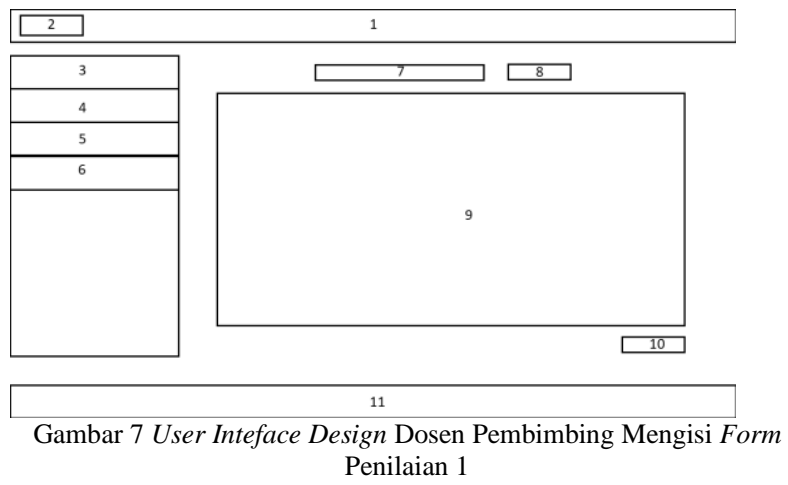

\subsection{Implementasi}

Batasan implementasi dalam mengimplementasi 
aplikasi sistem penilaian PPL yaitu, (1) Pendaftaran (Register) tidak ada karena data sudah diperoleh secara statis sehingga hanya perlu fungsi pemanggilan data saja untuk masuk (login); (2) akses hanya diberikan kepada dosen pembimbing, guru pamong, dan akademik. Mahasiswa tidak diberikan akses untuk menggunakan aplikasi sistem penilaian PPL karena fokus sistem hanya kepada para penilai. Pada Gambar 8 menunjukkan hasil implementasi user interface design dosen pembimbing mengisi form penilaian 1 .

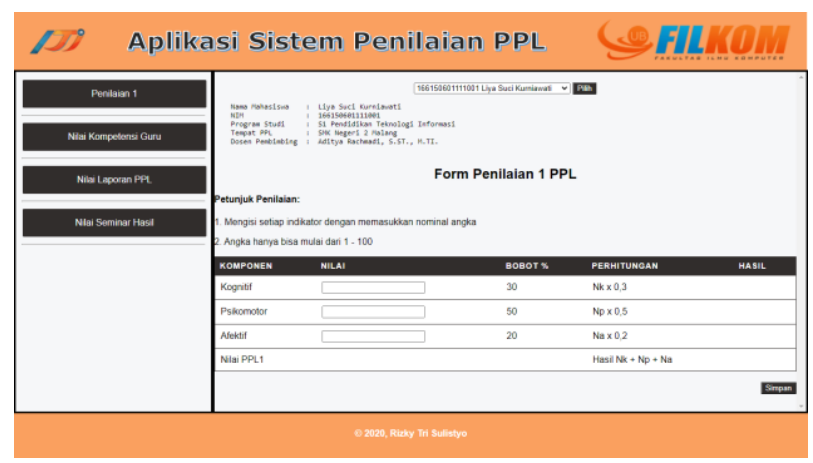

Gambar 8 Hasil Implementasi User Interface Design Dosen Pembimbing Mengisi Form Penilaian 1

\subsection{Pengujian}

Dilaksanakan pengujian white-box (pengujian unit dan integrasi), pengujian black-box (pengujian validasi), dan pengujian compatibility untuk memperoleh hasil valid dari tiap sampel uji dan kompatibel di berbagai peramban.

\subsubsection{Pengujian Unit}

Pengujian unit aplikasi sistem penilaian PPL menggunakan teknik basis path testing, sehingga pengembang akan menciptakan flow graph dari unit yang ada hasil dari identifikasi pada jalur independent path unit oleh pengembang. Pengujian unit menggunakan lima sampel uji, yaitu (1) mengisi form penilaian 1; (2) mengisi form nilai kompetensi guru; (3) mengisi form nilai laporan PPL; (4) mengisi form nilai seminar hasil; (5) memvalidasi penilaian akhir.

\subsubsection{Pengujian Integrasi}

Pengujian intregasi dilakukan untuk memastikan kesesuaian keluaran yang diharapkan dari perangkat lunak. Pengujian integrasi menggunakan fungsi kelas Controller_GuruPamong.

\subsubsection{Pengujian Validasi}

Pengujian validasi dilakukan untuk memastikan kebutuhan dari fungsional sistem memenuhi persyaratan dan berjalan sesuai dengan fungsinya sesuai dengan tiap pengguna sistem dengan akumulasi enam sampel uji yaitu (1) mengisi form penilaian 1 (UC-SIPPL-1); (2) mengisi form nilai kompetensi guru (UC-SIPPL-2); (3) mengisi form nilai laporan PPL (UC-SIPPL-1); (4) mengisi form nilai seminar hasil (UC-SIPPL-4); (5) mengisi form nilai kompetensi guru (UC-SIPPL-5); (6) memvalidasi form penilaian akhir (UC-SIPPL-6).

\subsubsection{Pengujian Compatibility}

Pengujian compatibility dilakukan untuk memastikan kebutuhan dari non-fungsional sistem layak memenuhi persyaratan dan berjalan sesuai dengan fungsinya sesuai dengan peramban yang digunakan. Pada Gambar 9 menunjukkan hasil pengujian compatibility menggunakan SortSite yang telah tercipta. Hasil pengujian kompatibilitas pada aplikasi sistem penilaian PPL menunjukkan ditemukan adanya critical issue ditandai simbol lingkaran merah pada Android versi tiga ke bawah dan major issue ditandai simbol lingkaran kuning pada peramban IE yang disebabkan oleh adanya CSS dengan menggunakan flex dan gambar dengan ekstensi SVG. Sehingga, menandakan sistem kompatibel dengan semua peramban uji namun dengan syarat untuk peramban bawaan di Android harus dimulai dari versi tiga ke atas.

\begin{tabular}{|c|c|c|c|c|c|c|c|c|c|c|}
\hline Browser & IE & Edge & Firefox & Safari & Opera & Chrome & & ios & And & \\
\hline Version & 11 & 79 & 72 & 13 & 66 & 79 & $\leq 11$ & 1213 & $\leq 3$ & $4^{*}$ \\
\hline Critical Issues & () & () & () & ( & $\odot$ & ( & () & () () & 0 & () \\
\hline Major Issues & (c) & () & () & () & () & () & () & () & & () \\
\hline Minor Issues & & () & () & () & () & () & () & (-) () & & ( ) \\
\hline
\end{tabular}

Gambar 9 Hasil Pengujian Compatibility Menggunakan SortSite

\subsubsection{Analisis Pengujian}

Analisis pengujian merupakan tahap dari pengembang untuk analisa dari tiap uji coba yang terlah dilakukan. Pengembang melakukan empat pengujian untuk menguji sistem, yaitu (1) pengujian unit; (2) pengujian integrasi; (3) pengujian validasi; (4) pengujian compatibility.

Pada pengujian unit dengan basis path testing yang menghasilkan tiga region, independet path, cyclomatic complexity dari tiap uji coba sesuai dengan lima sampel uji ditemukan akumulasi lima kasus uji menandakan $100 \%$ valid. Berlandaskan hasil uji dapat ditarik kesimpulan bahwa dari lima sampel uji yang diuji menggunakan metode pengujian unit menunjukkan struktur program yang dapat diimplementasi dan mudah dipahami.

Pada pengujian integrasi dengan pengujian integrasi yang dilakukan pada fungsi kelas Controller_GuruPamong untuk integrasi memutakhirkan nilai di basis data firestore. Fungsi db.collection ("penilaian") .doc(id) .update (\{Nkggp:Nkg_gp $\})$; mengirimkan data masukan berupa nilai untuk memperbarui dengan nilai masukan yang tampil di peramban dan menghasilkan (result) yang sesuai dengan hasil yang diharapkan (expected result) sehinga menandakan $100 \%$ valid. Berlandaskan hasil uji dapat ditarik kesimpulan bahwa pengujian integrasi pada kelas Controller_GuruPamong dapat dilaksankan oleh sistem dengan baik.

Pada pengujian validasi dengan kebutuhan fungsional dalam sistem dengan enam sampel uji ditemukan akumulasi enam kasus uji menandakan $100 \%$ 
valid. Berlandaskan hasil uji dapat ditarik kesimpulan bahwa dari enam sampel uji yang diuji menggunakan metode pengujian validasi menunjukkan keseluruhan kebutuhan fungsional dalam sistem dapat dijalankan dengan valid karena menghasilkan hasil (result) yang sesuai dengan hasil yang diharapkan (expected result).

Pada pengujian compatibility dengan menggunakan aplikasi SortSite. Sistem perangkat lunak SortSite menandakan sistem kompatibel dengan peramban 8 peramban, yaitu (1) IE; (2) Edge; (3) Firefox; (4) Safari; (5) Opera; (6) Chrome; (7) iOS; (8) Android namun dengan syarat untuk peramban bawaan di Android harus dimulai dari versi tiga ke atas.

\section{KESIMPULAN}

Pengujian pengembangan aplikasi sistem penilaian PPL pada FILKOM UB dikembangkan tanpa menggunakan framework dan dijalankan di berbagai peramban. Pengujian menggunakan pengujian white box (pengujian unit dan pengujian integrasi), pengujian black box (pengujian validasi), dan pengujian compatibility. Pengujian unit, integrasi, dan validasi menghasilkan valid terhadap semua fungsi sistem. Pengujian compatibility menghasilkan yang kompatibel dengan semua peramban, yaitu (1) IE; (2) Edge; (3) Firefox; (4) Safari; (5) Opera; (6) Chrome; (7) iOS; (8) Android. Namun ditemukan critical issue pada Android versi tiga ke bawah dan Major Issue pada IE karena menggunakan flex serta gambar dengan ekstensi SVG. Sehingga, menandakan aplikasi kompatibel dengan semua peramban uji dengan syarat untuk Android harus dimulai dari versi tiga ke atas .

\section{DAFTAR PUSTAKA}

FAISAL, R. \& HARISON, 2017. Aplikasi Penilaian Kinerja Dosen pada Proses Belajar Mengajar Berbasis Web: Studi Kasus di Badan Penjamin Mutu Internal Institut Teknologi Padang. Jurnal Teknologi dan Sistem Komputer, 5(2), pp. 8793.

MAHMUDI, A. A., 2015. Sistem Informasi Penilaian Kinerja Dosen dan Karyawan Berbasis Web. Surya Informatika, 1(1), pp. 55-60.

MARYONO, D. \& SURYADINI, F., 2017. Pengembangan Sistem Informasi Akademik Berbasis Web Sebagai Sistem Pengolahan Nilai Siswa di SMK Negeri 1 Kudus. Jurnal Ilmiah Pendidikan Teknik Kejuruan, 10(1), pp. 71-82.

PPL, T. P., 2018. Buku Panduan Penyelesaian dan Evaluasi Praktik Pengalaman Lapangan (PPL) Program Studi Pendidikan Teknologi Informasi. Malang: Fakultas Ilmu Komputer.

RAHMAWATI, U., ADITYA, B. R. \& WIKUSNA, W., 2016. Aplikasi Berbasis Web Pengolahan Nilai Akademik (Studi Kasus: SMP Negeri 34 Bandung). e-Proceeding og Applied Science, 2(3), pp. 974-980.

SOMMERVILE, I., 2016. Software Engineering.. 10th penyunt. United State: Pearson Education.
SUMBARYADI, A. \& CHRISTO, P., 2019. Sistem Informasi Penilaian Hasil Belajar Siswa Sekolah Menengah Kejuruan (SMK) Berbasis Web. Jurnal Sistem Informasi, 6(1), pp. 48-53. 
Halaman ini sengaja dikosongkan 